\title{
The impact of ownership and other corporate characteristics on performance of V4 companies
}

\author{
David Procházka \\ University of Economics, \\ Prague, Crech Republic \\ Email:prochazd@vse.cz.
}

Abstract. The objective of this paper is to assess financial performance of Czech, Hungarian, Polish, and Slovak unlisted companies. The sample retrieved from the Amadeus database contains 171,095 firm-year observations for the period of 2010-2014. A linear regression model (weighted least squares with robust correction for standard errors) is run to regress Return on Assets (ROA) as the dependent variable against selected entity-specific factors, including ownership characteristics. Empirical evidence uncovers several findings. Firstly, the performance of V4 companies is comparable except for Hungary, where companies report lower ROA on average. Secondly, firms established after the failure of communist regimes outperform the privatised companies. Thirdly, the ownership characteristics do matter. Having domestic owners is not a disadvantage, as only the companies with controlling shareholders from the Anglo-Saxon countries perform better. Other jurisdictions of parents lead either to comparable (e.g., old EU members, developed Asian countries) or even worse (e.g., new EU members, post-Soviet bloc) performance as compared to domestic ownership. Similarly, family firms perform significantly better than the companies controlled by institutional owners or by public sector, but worse than the firms controlled by financial institutions. The listing status of a parent is not an influential factor of performance. Fourthly, the size of a company also matters, as small enterprises report better performance in their financial statements than medium and large undertakings. Fifthly, higher leverage undermines performance. Finally, there is a wide dispersion in average performance across the industries. The study results might be relevant for policy makers while choosing between direct and indirect support for diverse types of businesses.

Keywords: performance, ROA, V4 countries, parent-subsidiary links.

JEL Classification: G31, M41 


\section{INTRODUCTION}

Since seminal review studies of (Short, 1994) and (Shleifer \& Vishny, 1997), the unpredictability of ownership structure on the quality of corporate governance and financial performance of companies is emphasised. Based on the agency theory (Jensen \& Meckling, 1976), empirical studies attempt to reflect, how divergent motivations of principals and agents (Fama \& Jensen, 1983) influence economic performance of companies under separated ownership and management. Potential negative outcomes of agency problem are believed to be mitigated by an appropriate design of incentives for managers (Shavell, 1979); (Gjesdal, 1982). Alternatively, market mechanisms may be another solution how to align managers' activity with owners' goals. The ownership structure - the presence of large shareholder or concentrated ownership (Shleifer \& Vishny, 1986) - can also reduce the loss of firm value by ineffective diversification of a company's operations preferred by risk-averse managers (Thomsen and Pedersen, 2000). Variability in financial performance across various ownership structures can be also explained by diverse types of owners.

For example, family firms prefer pursuing non-financial rather than financial goals (Zellweger et al., 2013). Despite becoming more active in recent years (Gillan \& Starks, 2000), institutional investors still play rather passive role in corporate governance and prefer investments in large firms with good governance, as a precondition of better operating performance, higher firm valuation and overall stability of returns (Ferreira and Matos, 2008). Contrariwise, venture capital providers are engaged intensively in the governance of start-ups (Bouresli et al., 2002) to capitalise as much as possible on the sale of their interests around IPO or through direct sale to another investor (Barry et al., 1990). Business combinations between companies within the industry can lead to another type of ownership structures, once again with a distinct impact on the financial results of acquired companies. Vertical integration of companies is driven by improving financial performance through economising (fixed) operating expenses (D'Aveni \& Ravenscraft, 1994) as well as with a view to retain value added through all stages of the production chain. On the other hand, the motives behind horizontal acquisitions and integrations are unclear, as the controlling company can pursue either value-creation (positive) or value-exploitation (negative) objectives (Yang et al., 2008), including the effort to destroy the acquired competitor. However, if the value-creation motive is beyond the decision, a positive impact of acquisition on the subsidiary's performance can be predicted.

There are other two important dimensions, which can shape the influence of ownership structure on company's performance, if a company is required by a foreign industry-investor. An acquiring company from a developed country usually transfers the intangible assets and working staff to a subsidiary in emerging markets, thus rearranging organisational structure and effectiveness of corporate governance policies of the subsidiary (Fey \& Björkman, 2001), (Luo, 2003). Consequently, the performance of subsidiary improves (Birkinshaw \& Hood, 1998), (Delios \& Beamish, 2001), (Fang et al., 2007), (Gaur et al., 2007). Secondly, if a subsidiary is located in a transition country, then transfers and implementation of global business practices from the parent can be expected (Procházka, 2012). The replacement of local practices as well as the emphasis on continuous improving of financial performance can have positive impact not only on a respective subsidiary, but on the whole economy (Albu et al., 2014). However, the results can differ significantly across countries, depending for example on the approach to privatisation selected by particular transition country (Mickiewicz, 2009).

The objective of this paper is to assess the actual financial performance of Czech, Hungarian, Polish, and Slovak (V4 countries) unlisted companies. The question of corporate performance was an immense political issue in the V4 countries, especially in the 1990s during the discussions about appropriate privatisation methods. However, the recent development is on the edge of public interest, despite all countries strive to find an optimal mix of governmental policies to support companies (e.g., through investment subsidies, tax reliefs etc.) and thus to boost economic growth. This is the main reason, why this 
study focuses on recent corporate data. Secondly, the unlisted companies are selected, as the capital markets in the former communist countries of the Central and Eastern Europe (expect for Poland) do not play a very important role in raising capital for financing business activities. Instead of home capital markets, financing depends on foreign investments. Furthermore, despite having similar institutional background, each V4 country opted for different methods during the transition from a command to a free-market economy. There were differences in economic performance of privatised companies at various stages of the privatisation process, depending on the extent of retained state ownership, the choice of privatization method, and firm size (Jelic et al., 2003). However, the transition has already finished - at least in terms of turbulent changes in ownership structures. The paper will therefore evaluate whether there are any differences among V4 countries regarding the actual performance of private companies, after controlling for potentially relevant determinants of their performance, such as the type of the controlling owner, its jurisdiction and listing status as well as individual characteristics of the inspected companies. The empirical analysis of data documents good performance of the companies with domestic owners as well as superior performance of small firms. These findings might be relevant for policy makers while deliberating about the form of direct and indirect support (such as investment grants, tax subsidies etc.) for diverse types of businesses and investors.

The paper is organised as follows. After the introduction, Section 2 finishes literature review, based on which the research hypotheses are posed. Research design is presented in Section 3, the empirical results are discussed in Section 4. Final section concludes and suggests potential future directions of research.

\section{LITERATURE REVIEW}

The question of company's performance was a political issue of the utmost interest in the V4 countries especially in 1990s during the discussions about appropriate privatisation methods. The privatisation outcomes were addressed as well by the researchers, concentrating on different approaches to privatisation opted by particular countries (mass voucher privatisation in the Czech Republic and Slovakia; mass privatisation and IPOs in Poland; direct sales and IPOs in Hungary). There are two types of studies inspecting the results of privatisation: country-specific studies and country-comparative analyses, which are reviewed in detail.

\subsection{Czech Republic and Slovakia}

(Claessens \& Djankov, 1999) on a sample of 706 Czech companies over 1992-1997 period uncover that more concentrated ownership results in higher profitability and labour productivity. Similarly, (Weiss and Nikitin, 1999) evidence an improvement in operating performance of Czech firms, once the changes in ownership concentration are completed, except for cases, when controlling shareholder is an investment fund. The influence of a selected privatisation method on the company's performance is also stressed by (Cull et al., 2002), indicating voucher-privatized joint stock companies during the period 1993-1996 performed worse than firms with concentrated shareholdings purchased for cash, because the former group had privileged access to soft credit financing from banks still being under control of the state by that time. (Harper, 2001) distinguishes short-term and long-term effects and provides with evidence that initial effects of privatisation on profitability and efficiency are rather negative. The positive change occurs after a longer period of time and it is stronger in nonmanufacturing industries.

Regarding the impact of foreign ownership, (Djankov \& Hoekman, 2000) study over the 1992-1996 confirms that foreign investments had a positive influence on the factor productivity growth of Czech firms receiving the investments. (Švejnar \& Kočenda, 2003) supports the previous findings that concentrated 
foreign ownership improves economic performance compared to state ownership. However, domestic ownership does not outperform the state ownership. The divergent development of Czech companies with or without foreign owners is explained by similar factors as general evidence on parent-subsidiary links, i.e. foreign parent companies managed the restructure of operating and financial activities resulting in growth of profit and sales. On the other hand, domestic firms suffered from shrinkage in sales, which was not compensated enough by reduction of labour expense. Following more than 10-year experience with the EU membership, the impact of privatisation method on corporate performance shall be waning and only "real factors" shall determine profitability and other measures of performance. From the recent studies, (Konečný \& Č́stek, 2016) identify an association between ownership concentration and performance on a sample of 5,000 firms in the period of 2010-2012. The findings contradict previous studies, as higher concentration of ownership has negative impact on performance, which lead authors to a conjecture that controlling owners abuse their power at the expense of other stakeholders.

\subsection{Poland and Hungary}

Similarly to the Czech Republic and Slovakia, Poland had selected the mass privatisation as one of the main channels of finding new owners of former state companies. In early stages, privatization was more successful in services and in retail trade, but privatization of (large) manufacturing firms was slow, which had an impact on performance (Pinto et al., 1993). The later studies focus on the characteristics of family firms. (Kowalewski et al., 2010) demonstrate the existence of an inverted U-shaped relationship between the share of family ownership and firm performance on a panel of 217 Polish companies over the period 1997 to 2005. Having a family-based CEO increases the likelihood to outperform competitors with hired nonfamily CEOs.

Privatisation strategy in Hungary and its impact on financial performance of privatised companies is examined e.g. by (Jelic \& Briston, 1999), who point out than Hungary chose a different approach compared to the Czech Republic or Poland. The Hungarian preference of direct sales and privatisation through Initial Public Offerings enables to assess the post-IPO performance of privatised companies compared to other IPOs. The analysis over the period 1990-1998 shows positive initial returns and greater under-pricing at the moment of privatisation, followed by the superior performance of firms privatised through IPO over other IPOs in the long run.(Campbell, 2002) investigates a sample of 162 large Hungarian enterprises in 1998 and 1999 and identifies that two variables have a significant impact on performance, namely firm size and capital intensity. The smaller firms in the sample outperform the larger firms (because of negative influence of agency costs). Capital intensity is positively correlated with performance.

\subsection{Open issues}

Empirical studies reviewed indicate a mixed evidence of the impact of ownership concentration, type of owners or location of owners on the economic performance of companies in transition countries of the CEE region. There might be several explanations of inconsistent findings. Firstly, short-term and long-term effects of changes in ownership structure may significantly differ; therefore, studies with a shorter investigated period may produce different outcomes compared to empirical tests over longer periods of time. Secondly, research methods employed for the assessment of performance vary enormously across papers. Operating, financial or capital market performance might be subject of interest. Distinct data sources are required for each of the methods; however, quality of underlying databases is questionable. Thirdly, financial performance in emerging/transition countries might be time-dependent. In the periods close to transition from a command economy to a market economy, the institutional effects (e.g. country's openness 
to foreign investments, speed of ownership concentration, development of legal framework, protection of minority investors) and privatisation methods play a crucial role (Jelic et al., 2003). Consequently, it may appear that there is no significant change in (operating) performance even six years after privatisation, as documented by (Aussenegg \& Jelic, 2007) because of the complexity of transition and underdeveloped institutions. However, as the time goes by, economic factors (being publicly traded, level of corporate governance, membership to MNE groups) start to dominate. Fourthly, companies within the samples are not homogenous in terms of preferable incentives to report truthfully own performance in financial statements. It could be reasonably expected that e.g. family firms will usually strive for such a depiction of profitability, which would minimise their tax burden. On the other hand, hired managers will prefer overstatement of financial performance, if this serves as a benchmark for their compensation.

Furthermore, even seemingly homogenous subgroups of companies may behave in a noticeably different way. (Procházka, 2016a), on a complete sample of Czech private firms under control of companies traded in the EU capital markets, unveils a wide dispersion in the effective tax rates. The empirical evidence provides with arguments that Czech subsidiaries participate in profit transfers either into or out of the Czech Republic depending on the country-domicile of the parent and the group's industry. The same sample was used in a follow-up research of performance, according to which performance measured by return on assets (ROA) is relatively evenly distributed across the sample, but significant differences in return on equity (ROE) are present (Procházka, 2016b). Furthermore, the values of ROA are, on average, higher than ROE, confirming thus profit shifting within the MNE groups, including Czech branches.

\section{RESEARCH DESIGN}

Literature review reveals a disproportion in research of corporate performance in the V4 countries over the time. Contrary to the considerable number of studies in early years of the privatisation, there is only fragmentary empirical evidence of recent development in the era of "stabilised conditions". Around a quarter of a century after the failure of communist regimes, the economies of the V4 region are (almost) completely transformed. The companies operate on the common EU market and they face to the standard market environment of a globalised economy. However, national-specific effects may still cause differences across the countries. The potential cross-country disproportions are also indicated by related previous studies reviewed above.

This study concentrates therefore on the period 2010-2014 to assess the impact of ownership and other corporate characteristics on performance of V4 companies. The starting year of investigation was selected to have a sufficient distance from the effects of different privatisation methods, as well as to eliminate the influence of the preceding financial crisis (spreading over the period 2007-2009). The ending year of the analysis was selected to avoid any misrepresentation of data because of delays in coverage of companies' financial statements in the database used.

\subsection{Hypotheses}

To proceed with the empirical analysis, the paper's goal is concretised into following hypotheses:

H1: There is no difference in performance of V4-companies.

H2: There is no difference in performance between old (privatised) companies and newly established companies.

H3: There is no difference in performance between companies under control of domestic vs foreign owners. 


\subsection{Sample}

Using the Amadeus database; all active Czech, Hungarian, Polish, and Slovakian private companies were extracted alongside with following data:

- fundamental financial figures (assets, equity, interest-bearing debts, revenue, EBIT, net income) for the period 2010-2014, based on which financial ratios (ROE, ROA, leverage) were calculated;

- entity-specific data: country code; industry code; date of incorporation; number of employees;

- data about an entity's immediate owners: country code; type of owner; listing status; share on subscribed capital.

To get a homogenous group of companies in terms of practicing ownership rights, only companies with controlling shareholders are included in the sample. Despite not an ideal approach, a controlling shareholder for the purpose of this paper is identified, if it holds more than $50 \%$ of subscribed share capital. To narrow the paper's scope, micro entities are dropped out of sample, leaving only large, medium, and small companies.

Table 1

Descriptive statistics of sample. Source: Own calculations based on Amadeus

\begin{tabular}{|c|c|c|c|c|c|c|c|c|}
\hline & & $\begin{array}{c}\text { Total } \\
\text { assets }\end{array}$ & Equity & Revenue & EBIT & EAT & ROE & ROA \\
\hline \multirow[t]{5}{*}{$\mathrm{CZ}$} & Min & 2 & 0 & 0 & $(564,518)$ & $(193,849)$ & $(100,0)$ & $(100,0)$ \\
\hline & Median & 2,285 & 965 & 3,604 & 141 & 91 & 11,3 & 6,4 \\
\hline & Max & $6,363,508$ & $4,384,502$ & $10,849,577$ & $1,012,947$ & 876,153 & 100,0 & 100,0 \\
\hline & Mean & 15,716 & 7,974 & 20,267 & 1,067 & 904 & 15,0 & 9,2 \\
\hline & SD & 113,602 & 71,810 & 146,977 & 10,560 & 10,002 & 31,7 & 13,8 \\
\hline \multirow[t]{5}{*}{ HU } & Min & 7 & 2 & 0 & $(270,913)$ & $(4,111,211)$ & $(100,0)$ & $(100,0)$ \\
\hline & Median & 7,093 & 2,333 & 9,825 & 294 & 210 & 11,4 & 5,5 \\
\hline & Max & $20,811,755$ & $9,259,404$ & $7,521,655$ & $1,063,291$ & $2,599,559$ & 100,0 & 100,0 \\
\hline & Mean & 83,775 & 41,819 & 72,242 & 3,223 & 2,046 & 13,8 & 7,0 \\
\hline & SD & 617,589 & 386,282 & 297,968 & 31,656 & 80,059 & 44,5 & 15,1 \\
\hline \multirow[t]{5}{*}{ PL } & Min & 0 & 0 & 0 & $(216,836)$ & $(259,709)$ & $(100,0)$ & $(100,0)$ \\
\hline & Median & 3,367 & 1,389 & 4,820 & 173 & 111 & 10,5 & 6,2 \\
\hline & Max & $8,507,345$ & $4,283,617$ & $8,433,037$ & 465,608 & 603,981 & 100,0 & 100,0 \\
\hline & Mean & 21,512 & 10,516 & 24,088 & 1,260 & 948 & 13,8 & 8,6 \\
\hline & SD & 135,584 & 75,882 & 129,853 & 8,896 & 8,159 & 34,2 & 15,4 \\
\hline \multirow[t]{5}{*}{ SK } & Min & 0 & 0 & 0 & $(461,520)$ & $(368,887)$ & $(100,0)$ & $(100,0)$ \\
\hline & Median & 1,900 & 541 & 3,253 & 102 & 61 & 14,3 & 5,8 \\
\hline & Max & $9,068,549$ & $5,843,892$ & $6,532,305$ & 600,134 & 746,872 & 100,0 & 100,0 \\
\hline & Mean & 21,020 & 10,397 & 21,275 & 1,122 & 935 & 19,4 & 9,1 \\
\hline & SD & 216,325 & 125,553 & 151,983 & 12,756 & 12,252 & 39,9 & 16,3 \\
\hline
\end{tabular}

Note: number of observations - CZ 63,216; HU 5,943; PL 81,260; SK 20,676 
For the determination of an undertakings' type, the definitions from the Directive 2013/34/EU are used. After eliminating records with incomplete data (e.g. missing information on total assets, profit for the period, etc.), 171,095 firm-year observations constitute the sample. Similarly, the companies with negative equity are excluded from the sample, as the interpretability of ROE ratio is difficult (e.g. negative profit combined with negative equity would produce positive ROE, which is in fact not a positive thing). The above-described exclusions will presumably lead to higher values of financial performance indicators. The descriptive statistics are presented in Tab. 1.

Two fundamental metrics of financial performance utilising accounting data are calculated, namely Return on Equity (ROE) and Return on Assets (ROA). To eliminate the results' distortion because of extreme observations, the minimum and maximum of ROE and ROA are limited to $100 \%$ in absolute terms. The extreme values usually occur when the denominators (equity or assets) are close to zero.

As it can be seen from Tab. 1, both median and mean value of ROE is higher than ROA for all four analysed countries. The best return on equity is reached by Slovakian firms; Czech companies outperform the firms from other countries in case of return on total assets.

\subsection{Research method}

The research hypotheses will be tested using a linear regression model. Referring to previous literature, fundamental data from financial statements are used to compute two standard financial analysis ratios of performance - ROE and ROA - as a potential dependent variable. However, three restrictions on $\mathrm{ROE} / \mathrm{ROA}$ as a measure of performance based on accounting data shall be mentioned. Firstly, accounting is just a simplified model trying to depict real economic phenomena, although not in a perfect form. This general measurement error cannot be removed. Secondly, the overwhelming majority of companies covered by the sample report under national GAAP, which may vary significantly against each other. The comparability of results is therefore questionable. Thirdly, from the very definition of control stems that parent company has power over the subsidiary so that it can manage its operating and financing activities in a way that enables the parent to reach its goals. The parent may influence the display of the economic condition of the group's entities in their financial statements by transfer pricing. Moreover, the parents may force their subsidiaries to engage in such transactions, which are not economically justifiable from the subsidiary's perspective. Via transfer pricing or artificially designed intragroup transactions, the subsidiary can be subject of profit shifting in or out depending on the favourability of tax regimes in different countries, where the group operates. Similarly, the parent may be tempted to tune the intercompany operations to meet own debt covenants and other financial indicators.

The third factor restricts seriously the utilisation of individual financial statements of subsidiaries under control of another business entity for the evaluation of its stand-alone financial performance. External users cannot detect the exact extent of potential manipulation and profit shifting within the group and its impact on content of individual financial statements of each company. To remove the unclear impact of intercompany transactions on financial performance, the criterion of ROA is preferred, as it excludes interest expense (a major item in within-the-group profit shifting) from the calculation of profit and is thus less prone to distortion because of manipulation.

\subsection{Model and variables description}

The regression model is defined as follows: 


$$
\begin{aligned}
R O A & =\beta_{0}+\beta_{1} * \text { Country }+\beta_{2} * \text { History }+\beta_{3} * \text { PCountry }+\beta_{4} * \text { PType }+\beta_{5} * \text { PStatus }+ \\
& +\beta_{6} * \text { Undertakings }+\beta_{7} * N A C E+\beta_{8} * \text { Leverage }+\varepsilon
\end{aligned}
$$

Tab. 2 summarises the description of independent variables, their values and expected impact on the dependent variable.

Table 2

\begin{tabular}{|c|c|c|c|}
\hline Variable & Description & Values & $\begin{array}{l}\text { Expected direction on } \\
\text { "ROA" }\end{array}$ \\
\hline ROA & $\begin{array}{c}\text { ROA }=\underset{\text { Essets }}{\text { EBIT } / \text { Total }} \\
\text { as }\end{array}$ & $(100 \%)$ to $100 \%$ & $\mathrm{xxx}$ \\
\hline Country & V4 countries & $\begin{array}{c}\text { Czech Republic (CZ) } \\
\text { Hungary (HU) } \\
\text { Poland (PL) } \\
\text { Slovakia (SK) } \\
\end{array}$ & Indecisive \\
\hline History & $\begin{array}{l}\text { Incorporation date of } \\
\text { company }\end{array}$ & $\begin{array}{c}\underline{\mathbf{E U}} \Leftrightarrow \text { } \Leftrightarrow \text { after } 2004 \\
\text { Post-com } \Leftrightarrow 1990-2004 \\
\text { Com } \Leftrightarrow \text { before } 1990\end{array}$ & Indecisive \\
\hline PCountry & $\begin{array}{l}\text { Country domicile of } \\
\text { controlling owner }\end{array}$ & $\begin{array}{c}\text { Domestic } \\
\text { EU-old members } \\
\text { EU-new members } \\
\text { Europe rest } \\
\text { Anglo-Saxon world } \\
\text { Post-Soviet bloc } \\
\text { Tax havens } \\
\text { Arabic countries } \\
\text { Latin America rest } \\
\text { Africa rest } \\
\text { Asia rest }\end{array}$ & $\begin{array}{l}\text { Companies with parents } \\
\text { domiciled in developed } \\
\text { countries (EU-old, Europe } \\
\text { rest, Anglo-Saxon) should } \\
\text { perform better than } \\
\text { companies with domestic } \\
\text { controlling owners }\end{array}$ \\
\hline PType & Type of controlling owner & $\begin{array}{c}\text { Family firm } \\
\text { Industry owner } \\
\text { Financial institution } \\
\text { Institutional investors } \\
\text { Foundation/non-profit } \\
\text { State ownership }\end{array}$ & $\begin{array}{l}\text { Companies with parents } \\
\text { operating in the same } \\
\text { industry shall perform } \\
\text { better } \\
\text { State ownership shall result } \\
\text { in worse performance }\end{array}$ \\
\hline PStatus & $\begin{array}{l}\text { Listing status of } \\
\text { controlling owner }\end{array}$ & $\underline{\text { Listed }}$ & $\begin{array}{l}\text { Firms with listed parent } \\
\text { shall perform better }\end{array}$ \\
\hline Undertakings & $\begin{array}{c}\text { Size of company based on } \\
\text { Directive } 2013 / 34 / \mathrm{EU}\end{array}$ & $\begin{array}{l}\text { Small } \\
\text { Medium } \\
\text { Large }\end{array}$ & $\begin{array}{l}\text { Large companies are } \\
\text { expected to perform better } \\
\text { (if agency costs do not } \\
\text { overweight economies of } \\
\text { scale) }\end{array}$ \\
\hline NACE & $\begin{array}{l}\text { Industry classification of } \\
\text { subsidiary }\end{array}$ & A-S & $\begin{array}{l}\text { Expected differences in } \\
\text { ROA across industries }\end{array}$ \\
\hline Leverage & $\begin{array}{c}\text { Share of interest-bearing } \\
\text { debts on total assets }\end{array}$ & Interval value & $\begin{array}{l}\text { Indecisive (depends on the } \\
\text { validity of optimal capital } \\
\text { structure hypothesis in each } \\
\text { individual case) }\end{array}$ \\
\hline
\end{tabular}

Description of variables

Note: variables underlined in bold are treated as basic reference values 
The variable COUNTRY captures the legal jurisdiction of companies investigated. As comparative studies on performance across V4 countries are rare and are dated mainly to the immediate postprivatisation era, no assumption on differences is made. However, based on descriptive statistics in Tab. 1 (as well as based on the highest GDP per capita among V4 countries), it could be reasonably expected that Czech companies will record the best performance after controlling for other effects. The variable HISTORY addresses potential impact of different length of operating in business. However, the exact impact is unpredictable. For example, the companies with longer history may capitalise on their tight relations with customers, but in case of transition countries, the imperfect privatisation or ignorance of market pressures may have curtailed these benefits. On the other hand, recently established undertakings do not suffer from post-communist heritage, but they may not be able to penetrate the markets successfully. Referring to the literature review, superior performance of V4 companies under control of owners from developed countries is expected, compared to domestic ownership. Foreign direct investments are always connected with risks stemming from incompatibility of cultural, social, legal, and economic institutions in the target country. Therefore, the variable PCOUNTRY refines the domicile of controlling shareholders to control for potential dispersion in institutional background within different owners' subgroups.

The independent variable PTYPE deals with familiarity of owners with an entity's business, including whether it could be expected an active or passive participation on corporate governance and performance management in controlled entities. If a company is controlled by the parent operating in the same industry, better performance compared to family ownership is expected, as transfers of knowhow, shared distribution channels and advertisement campaigns shall promote the effectiveness of subsidiaries. The variable PSTATUS reflects the fact that the exposure of listed companies to meet or beat expectations of capital market participants is higher than the pressures on performance of unlisted companies. Finally, there are three controlling variables taking into account differences in companies because of their size (UNDERTAKINGS is a combined measure classifying the size of companies based on their turnover, total assets, and number of employees), industry affiliation (NACE), and indebtedness (LEVERAGE).

\section{RESULTS AND DISCUSSION}

The variation in ROA for the different cases of a categorical explanatory variable is tested by the Kruskal-Wallis test. For each such variable (Country, NACE, History, PCountry, PType, PStatus, and Leverage), the p-values of $\mathrm{KW}$ test are equal to zero, evidencing thus differences in ROA across investigated countries, across industries, across owners' types, etc.

Table 3

Univariate (Kruskall-Wallis) tests

\begin{tabular}{|l|c|c|c|}
\hline \multicolumn{1}{|c|}{ Variable } & KW test & df & p-value \\
\hline Country & 199.9 & 3 & 0.000 \\
\hline History & $1,288.1$ & 2 & 0.000 \\
\hline PCountry & $1,428.4$ & 10 & 0.000 \\
\hline PType & $5,800.8$ & 5 & 0.000 \\
\hline PStatus & 85.9 & 1 & 0.000 \\
\hline Undertakings & $1,251.9$ & 2 & 0.000 \\
\hline NACE & $3,846.8$ & 18 & 0.000 \\
\hline
\end{tabular}

Note: calculated in $\mathrm{R}$ 
Furthermore, Tab. 4 presents the correlation matrix of the model's variables. Over the diagonal, Spearman's correlation coefficients are shown; Pearson's coefficients are below. The correlations for almost all Spearman's pairs are statistically significant (mostly with p-value $=0$ ), except for the relation between Leverage and Country, where no significant differences are found regarding the corporate indebtedness across V4 countries. Despite statistically significant, there are no extremely high values of correlations, which would raise the risk of multicollinearity.

Table 4

Correlation matrix

\begin{tabular}{|l|c|c|c|c|c|c|c|c|c|}
\hline & Country & NACE & History & PCountry & PType & PStatus & Undertak & Leverage & ROA \\
\hline Country & $\mathrm{x}$ & $0.051^{*}$ & $(0.025)^{*}$ & $0.06)^{*}$ & $0.096^{*}$ & $(0.039)^{*}$ & $0.058^{*}$ & 0.002 & $(0.022)^{*}$ \\
\hline NACE & $0.048^{*}$ & $\mathrm{x}$ & $(0.089)^{*}$ & $(0.034)^{*}$ & $0.043^{*}$ & $(0.028)^{*}$ & $(0.070)^{*}$ & $(0.116)^{*}$ & $(0.021)^{*}$ \\
\hline History & $(0.006)^{* *}$ & $(0.073)^{*}$ & $\mathrm{x}$ & $(0.031)^{*}$ & $0.093^{*}$ & $(0.017)^{*}$ & $0.137^{*}$ & $0.031^{*}$ & $(0.058)^{*}$ \\
\hline PCountry & $0.069^{*}$ & $(0.051)^{*}$ & $(0.041)^{*}$ & $\mathrm{x}$ & $0.395^{*}$ & $(0.332)^{*}$ & $0.177^{*}$ & $(0.205)^{*}$ & $0.068^{*}$ \\
\hline PType & $0.113^{*}$ & $0.072^{*}$ & $0.113^{*}$ & $0.327^{*}$ & $\mathrm{x}$ & $(0.352)^{*}$ & $0.286^{*}$ & $(0.166)^{*}$ & $(0.097)^{*}$ \\
\hline PStatus & $(0.046)^{*}$ & $(0.023)^{*}$ & $(0.016)^{*}$ & $(0.293)^{*}$ & $(0.315)^{*}$ & $\mathrm{x}$ & $(0.183)^{*}$ & $0.180^{*}$ & $(0.022)^{*}$ \\
\hline Undertak & $0.069^{*}$ & $(0.045)^{*}$ & $0.136^{*}$ & $0.154^{*}$ & $0.265^{*}$ & $(0.168)^{*}$ & $\mathrm{x}$ & $0.063^{*}$ & $(0.085)^{*}$ \\
\hline Leverage & $0.004^{* * *}$ & $(0.028)^{*}$ & $(0.022)^{*}$ & $(0.060)^{*}$ & $(0.062)^{*}$ & $0.060^{*}$ & $0.041^{*}$ & $\mathrm{x}$ & $(0.126)^{*}$ \\
\hline ROA & $(0.009)^{*}$ & 0.003 & $(0.067)^{*}$ & $0.042^{*}$ & $(0.072)^{*}$ & $(0.013)^{*}$ & $(0.081)^{*}$ & $(0.064)^{*}$ & $\mathrm{x}$ \\
\hline
\end{tabular}

Note: a) Spearman coefficient over diagonal; Pearson below diagonal

b) significance levels: *1\%; **5\%;***10\%

Estimation of the regression model parameters is processed by weighted least squares to control for the heteroscedasticity identified during regression diagnostic of the basic ordinary least squares linear model. For calculating robust standard errors, the HC3 version of heteroscedasticity consistent covariance matrix (MacKinnon and White, 1985) is applied as recommended by (Long and Ervin, 2000). ${ }^{1}$ The regression results are captured by Tab. 5 (because of space restriction, the detailed outcomes of NACE categories are not displayed).

Regarding the H1, the best performing are companies from the Czech Republic with comparable performance of Slovakian and Polish firms. Their average ROA (other variables fixed) is lower by about 0.2 percentage points and this difference is statistically insignificant. Only lower performance of Hungarian companies (by 2.46 percentage points) is statistically significant (p-value 0.024). As far as H2 concerns, companies established after the EU accession outperform firms with longer history - the difference is

1 To test robustness of the results, we run alternative calculations of standard errors and p-values based on HC1 and HC2 methods suggested also by (Long \& Ervin, 2000). The conclusions regarding statistical significance of the coefficients in regression model remain unchanged. 
significant only in comparison with companies existing already during the communist regime (variable History-Privatised with difference of 2.199 p.p. and p-value of 0.029). On average, privatised companies present worse economic results in their financial statements, but they are still able to survive. Future research may investigate more in detail the frequency of bankruptcies of "older" and "newer" undertakings. The regression model reveals interesting findings in case of H3. Domestic ownership leads to a better performance compared to the situation, when controlling shareholders are from former Soviet bloc (by 9.215 p.p. at $1 \%$ significance level); other new EU countries (by 6.137 p.p. at 5\% significance level), Arabian region (by 5.068 p.p. at 1\% significance level) or other European countries outside the EU (by 3.245 p.p. at $10 \%$ significance level). On the other hand, if the controlling owners come from Anglo-Saxon countries, then their subsidiaries in V4 outperform other competitors (by 12.501 p.p. at 1\% significance level). Other discrepancies are not statistically significant. Surprisingly, it is also true for companies having owners from the old EU countries. New evidence from recent years is thus opposite to the findings of (Švejnar \& Kočenda, 2003) from early stages of privatisation process, which may lead to a conjecture that the transition has really been completed.

Table 5

WLS regression

\begin{tabular}{|c|c|c|c|}
\hline Variable & Estimate & Standard error & $\mathbf{P}$-value \\
\hline (Intercept) & 13.908 & 1.543 & 0.000 \\
\hline Country-HU & -2.460 & 1.090 & 0.024 \\
\hline Country-PL & -0.237 & 0.774 & 0.759 \\
\hline Country-SK & -0.206 & 1.389 & 0.882 \\
\hline History-Postcom & -0.443 & 1.401 & 0.752 \\
\hline History-Privatised & -2.199 & 1.009 & 0.029 \\
\hline PCountry-Africa & 1.001 & 2.212 & 0.651 \\
\hline PCountry-Anglo & 12.501 & 2.516 & 0.000 \\
\hline PCountry-Arab & -5.068 & 1.520 & 0.001 \\
\hline PCountry-Asia & 2.069 & 1.605 & 0.197 \\
\hline PCountry-EUnew & -6.137 & 2.653 & 0.021 \\
\hline PCountry-EUold & 0.238 & 1.132 & 0.833 \\
\hline PCountry-Europe & -3.245 & 1.680 & 0.053 \\
\hline PCountry-Haven & -2.081 & 1.827 & 0.255 \\
\hline PCountry-LA & -0.759 & 1.617 & 0.639 \\
\hline PCountry-Soviet & -9.215 & 2.205 & 0.000 \\
\hline PType-Financial & 8.047 & 1.371 & 0.000 \\
\hline PType-Foundation & 2.526 & 1.442 & 0.080 \\
\hline PType-Industry & -0.997 & 1.110 & 0.369 \\
\hline PType-Institutional & -2.906 & 1.068 & 0.007 \\
\hline PType-State & -3.808 & 0.934 & 0.000 \\
\hline PStatus-Unlisted & 1.419 & 0.991 & 0.152 \\
\hline Undertakings-Large & -5.474 & 0.876 & 0.000 \\
\hline Undertakings-Medium & -4.137 & 0.713 & 0.000 \\
\hline Leverage & -0.072 & 0.022 & 0.001 \\
\hline \multicolumn{4}{|c|}{$\begin{array}{l}\text { Multiple R-squared: } 0.2298 \quad \text { Adjusted R-squared: } 0.2296 \\
\text { F-statistic: } 1215 \text { on } 42 \text { and 171052 DF, p-value: } 0.000\end{array}$} \\
\hline
\end{tabular}

Note: (a) calculated in R using packages "stats" and "sandwich"; (b) basic variant of the company in the model: small Czech domestically controlled family firm, established after the EU accession 
Regarding remaining control variables, the type of ownership does matter. Family firms perform significantly (at 1\% significance level) better compared to companies controlled by public sector or by institutional owners and no change has occurred since 1990's as evidenced by (Claessens \& Djankov, 1999) or (Weiss \& Nikitin, 1999) in case of the Czech Republic. The association between institutional investors and higher performance (Ferreira and Matos, 2008) is not confirmed in case of V4 countries. Contrariwise, the membership to a group controlled by financial institution increases ROA by more than 8 percentage points (at 1\% significance level). Listing status of the parent company does not affect performance, which means that both listed and unlisted parent companies are engaged in earnings management of their V4 subsidiaries, if any, in similar manner on average. The size of company is an important factor. Small companies (as defined by EU Directive) report higher values of ROA, which provides another evidence that agency costs in larger undertakings may overweight obtained economies of scale. This finding is similar to (Campbell, 2002) in case of Hungarian experience. The higher leverage, the lower performance, i.e. a heavier reliance on interest-bearing debts reduces ROA (other things unchanged). Finally, the regression shows also huge dispersion in ROA across industries. These findings extend similar evidence of (Procházka, 2016b) on the sample of Czech companies under control of the EU listed firms to all V4 companies.

\section{CONCLUSION}

The paper assesses the financial performance - measured by Return on Assets (ROA) - of V4 companies. The scope is restricted to unlisted companies with identifiable controlling shareholders (having an ownership interest over $50 \%$ of share capital). Using linear regression model (weighted least squares with robust correction for standard error), several conclusions can be made. Firstly, the performance of V4 companies is comparable except for Hungary, whose companies report lower ROA on average. Secondly, firms established after the failure of communist regimes outperform the privatised companies. Thirdly, the ownership characteristics do matter. Having domestic owners is not a disadvantage, as only companies with controlling shareholders from Anglo-Saxon countries perform better. Other jurisdictions of parents lead either to comparable (e.g. old EU members, Asia) or even worse (e.g. new EU members, post-Soviet bloc) performance compared to domestic ownership. Similarly, family firms perform significantly better than companies controlled by institutional owners or by public sector, but worse than firms controlled by financial institutions. The listing status of the parent is not an influential factor of performance. Fourthly, the size of company does matter and small enterprises report better performance in their financial statements than medium and large undertakings. Fifthly, higher leverage undermines the performance. Finally, there is a wide dispersion in average performance across industries.

On the other hand, there are additional restrictions to validity of the results than those mentioned in Section 3.3. Firstly, only companies having controlling owners are included in the sample. The proportion of effectively controlled and dispersedly controlled companies may differ in population of V4 countries and the sample might not produce representative comparisons. Furthermore, the control over sample firms is defined in terms of the interest in share capital, which is not utterly precise proxy of control. Secondly, the paper focuses on private companies only; listed undertakings are left outside the scope. However, public firms are usually largest business entities in country and their exclusion may distort aggregate country's results in relative comparison to other countries. This restriction may penalise especially Poland, which has significantly bigger capital market than other V4 countries (Procházka \& Pelák, 2015). Thirdly, ROA and ROE measures are based on accounting figures. Sample entities report under local GAAPs or IFRS, which are not fully comparable, causing thus potential bias of the results. 
The paper's findings have several implications. Small undertakings with clearly identified domestic family owners operate their businesses in highly profitable manner, which may be explained either by nonexistence of agency costs, or by higher flexibility in daily operations, or by missing incentives (or by restricted possibilities) to manage earnings. The positive influence of foreign owners is strikingly evident, only if the owners come from developed countries (mainly if they are of Anglo-Saxon origin). Contrariwise, owners located in developing countries have rather negative impact on the performance. Those compounding findings confirm previous evidence from general business research on parent-subsidiary links. In addition, the mixed results regarding the organisational type of the owners (family firms, financial institutions, institutional investors) raise concerns about appropriate functioning of corporate governance and its impact on performance. This question shall be addressed by future research, as well as further investigation of determinants of differences in relative performance across various industry vs parent-domicile subgroups.

The paper's findings have also practical implication esp. for governments and other policy makers. Many countries try to attract big direct foreign investments to boost an economic growth through creating new jobs and increasing of the production and consumption. To succeed, the governments offer various incentives like tax reliefs, investment subsidies, co-financing of employees' training. However, the results of this study show that big companies might contribute to economic growth hugely in absolute terms, but their relative performance is not (on average) better compared to small companies. Furthermore, domestic (family) firms tackle with the competition successfully, despite not having such advantageous access to know-how like their peers belonging to the multinational groups. Policy makers shall therefore carefully consider the impact of their direct and indirect support to diverse types of businesses and investors in order not to destroy competitive advantages of small domestic undertakings.

\section{ACKNOWLEDGEMENTS}

This paper has been prepared within the research project „Economic Impacts of the IFRS Adoption in Selected Transition Countries" (supported by the Czech Science Foundation, No. 15-01280S).

\section{REFERENCES}

Albu, N., Lupu, I., \& Sandu, R. (2014). Multinationals as vectors of corporate governance improvement in emerging economies in Eastern Europe: a case study. In Corporate Governance in Emerging Markets (pp. 331-349). Springer Berlin Heidelberg.

Aussenegg, W., \& Jelic, R. (2007). The operating performance of newly privatised firms in Central European transition economies. European Financial Management, 13(5), 853-879. doi:10.1111/j.1468-036X.2007.00400.x

Barry, C. B., Muscarella, C. J., Peavy, J. W., \& Vetsuypens, M. R. (1990). The role of venture capital in the creation of public companies: Evidence from the going-public process. Journal of Financial economics, 27(2), 447-471. doi:10.1016/0304-405X(90)90064-7

Birkinshaw, J., \& Hood, N. (1998). Multinational subsidiary evolution: Capability and charter change in foreign-owned subsidiary companies. Academy of management review, 23(4), 773-795. doi:10.5465/AMR.1998.1255638

Bouresli, A. K., Davidson III, W. N., \& Abdulsalam, F. A. (2002). Role of venture capitalists in IPO corporate governance and operating performance. Quarterly Journal of Business and Economics, 41, 71-82.

Campbell, K. (2002). Ownership structure and the operating performance of Hungarian firms. Centre for the Study of Economic and Social Change in Europe.

Claessens, S., \& Djankov, S. (1999). Ownership concentration and corporate performance in the Czech Republic. Journal of comparative economics, 27(3), 498-513. doi:10.1006/jcec.1999.1598

Cull, R., Matesova, J., \& Shirley, M. (2002). Ownership and the temptation to loot: Evidence from privatized firms in the Czech Republic. Journal of Comparative Economics, 30(1), 1-24. doi:10.1006/jcec.2001.1754 
D'aveni, R. A., \& Ravenscraft, D. J. (1994). Economies of integration versus bureaucracy costs: does vertical integration improve performance?. Academy of management Journal, 37(5), 1167-1206. doi:10.2307/256670

Delios, A., \& Beamish, P. W. (2001). Survival and profitability: The roles of experience and intangible assets in foreign subsidiary performance. Academy of Management journal, 44(5), 1028-1038. doi:10.2307/3069446

Djankov, S., \& Hoekman, B. (2000). Foreign investment and productivity growth in Czech enterprises. The World Bank Economic Review, 14(1), 49-64. doi:10.1093/wber/14.1.49

Fama, E. F., \& Jensen, M. C. (1983). Separation of ownership and control. The journal of law and Economics, 26(2), 301325.

Fang, Y., Wade, M., Delios, A., \& Beamish, P. W. (2007). International diversification, subsidiary performance, and the mobility of knowledge resources. Strategic Management Journal, 28(10), 1053-1064. doi:10.1002/smj.619

Ferreira, M. A., \& Matos, P. (2008). The colors of investors' money: The role of institutional investors around the world. Journal of Financial Economics, 88(3), 499-533. doi:10.1016/j.jfineco.2007.07.003

Fey, C. F., \& Björkman, I. (2001). The effect of human resource management practices on MNC subsidiary performance in Russia. Journal of international business studies, 32, 59-75. doi:10.1057/palgrave.jibs.8490938

Gaur, A. S., Delios, A., \& Singh, K. (2007). Institutional environments, staffing strategies, and subsidiary performance. Journal of Management, 33(4), 611-636. doi:10.1177/0149206307302551

Gillan, S. L., \& Starks, L. T. (2000). Corporate governance proposals and shareholder activism: The role of institutional investors. Journal of financial Economics, 57(2), 275-305. doi:10.1016/S0304-405X(00)00058-1

Gjesdal, F. (1982). Information and incentives: the agency information problem. The Review of Economic Studies, 49(3), 373-390.

Harper, J. T. (2001). Short-term effects of privatization on operating performance in the Czech Republic. Journal of Financial Research, 24(1), 119-131. doi:10.1111/j.1475-6803.2001.tb00821.x

Jelic, R., \& Briston, R. (1999). Hungarian privatisation strategy and financial performance of privatised companies. Journal of Business Finance \& Accounting, 26(9-10), 1319-1357. doi:10.1111/1468-5957.00300

Jelic, R., Briston, R., \& Aussenegg, W. (2003). The choice of privatization method and the financial performance of newly privatized firms in transition economies. Journal of Business Finance \& Accounting, 30(7-8), 905-940. doi:10.1111/1468-5957.05583

Jensen, M. C., \& Meckling, W. H. (1976). Theory of the firm: Managerial behavior, agency costs and ownership structure. Journal of financial economics, 3(4), 305-360.

Konečný, L., \& Částek, O. (2016). The Effect of Ownership Structure on Corporate Financial Performance in the Czech Republic. Ekonomický časopis, 64, 477-498.

Kowalewski, O., Talavera, O., \& Stetsyuk, I. (2010). Influence of family involvement in management and ownership on firm performance: Evidence from Poland. Family Business Review, 23(1), 45-59. doi: $10.1177 / 0894486509355803$

Long, J. S., \& Ervin, L. H. (2000). Using heteroscedasticity consistent standard errors in the linear regression model. The American Statistician, 54(3), 217-224. doi:10.2307/2685594

Luo, Y. (2003). Market-seeking MNEs in an emerging market: How parent-subsidiary links shape overseas success. Journal of International Business Studies, 34(3), 290-309. doi:10.1057/palgrave.jibs.8400027

MacKinnon, J. G., \& White, H. (1985). Some heteroskedasticity-consistent covariance matrix estimators with improved finite sample properties. Journal of econometrics, 29(3), 305-325. doi:10.1016/0304-4076(85)90158-7

Mickiewicz, T. M. (2009). Hierarchy of governance institutions and the pecking order of privatisation: Central-Eastern Europe and Central Asia reconsidered. Post-communist economies, 21(4), 399-423. doi:10.1080/14631370903339823

Pinto, B., Belka, M., Krajewski, S., \& Shleifer, A. (1993). Transforming state enterprises in Poland: Evidence on adjustment by manufacturing firms. Brookings papers on economic activity, 1993(1), 213-270. doi:10.2307/2534605

Procházka, D. (2016a). Effective Tax Rates in the "Foreign Parent - Czech Subsidiary" Links, in: Sedmihradská, L. (Ed.). Proceedings of the 21st International Conference: Theoretical and Practical Aspects of Public Finance 2016. Oeconomica, Prague, $70-78$.

Procházka, D. (2016b). Financial Performance of Czech Subsidiaries under Control of the EU Listed Companies. European Financial Systems, 2016, 623-629. 
Procházka, D. (2012, June). Development of Financial and Management Accounting Systems of Czech Companies after the IFRS Adoption. In Proceedings of the International Conference Accounting and Management Information Systems (Vol. 7, No. 1, pp. 871-887).

Procházka, D., \& Pelák, J. (2015). The development of capital markets of new eu countries after the ifrs adoption. Procedia Economics and Finance, 25, 116-126. doi:10.1016/S2212-5671(15)00720-0

Shavell, S. (1979). Risk sharing and incentives in the principal and agent relationship. The Bell Journal of Economics, 10, $55-73$.

Shleifer, A., \& Vishny, R. W. (1997). A survey of corporate governance. The Journal of Finance, 52(2), 737-783. doi:10.1111/j.1540-6261.1997.tb04820.x

Shleifer, A., \& Vishny, R. W. (1986). Large shareholders and corporate control. Journal of political economy, 94(3, Part 1), 461-488.

Short, H. (1994). Ownership, control, financial structure and the performance of firms. Journal of economic surveys, 8(3), 203-249.

Kocenda, E., \& Svejnar, J. (2003). Ownership and firm performance after large-scale privatization.

Thomsen, S., \& Pedersen, T. (2000). Ownership structure and economic performance in the largest European companies. Strategic Management Journal, 21, 689-705. doi:10.1002/(SICI)1097-0266(200006)21:6

Weiss, A., \& Nikitin, G. (1998). Performance of Czech companies by ownership structure. SSRN Electronic Journal. doi:10.2139/ssrn.148834

Yang, Q., Mudambi, R., \& Meyer, K. E. (2008). Conventional and reverse knowledge flows in multinational corporations. Journal of Management, 34(5), 882-902. doi:10.1177/0149206308321546

Zellweger, T. M., Nason, R. S., Nordqvist, M., \& Brush, C. G. (2013). Why do family firms strive for nonfinancial goals? An organizational identity perspective. Entrepreneurship Theory and Practice, 37(2), 229-248. doi:10.1111/j.1540-6520.2011.00466.x 